\title{
Repression of the Neo-Biafra Movement - Measures, Responses, and Consequences
}

\author{
Olalekan Waheed Adigun \\ Department of Political Science, University of Lagos, Akoka, Nigeria
}

Tel: 234-813-650-2040, 234-708-190-1080Ｅ-mail: adgorwell@gmail.com

Received: April 22, 2018 Accepted: May 20, 2018 Published: May 22, 2018

doi: 10.5296/jsss.v5i2.13180 URL: http://doi.org/10.5296/jsss.v5i2.13180

\begin{abstract}
This paper analyses the measures, reactions, and consequences of the repression of the neo-Biafra movement in Nigeria using longitudinal qualitative research. To go about this, the paper looks at the political context within which the movement operates, it objectives, and its activities are described. The movement started in September 1999 in reaction to perceived marginalisation and victimisation of Nigerians of Igbo ethnic origins by the state. The movement has had visible impacts on Nigeria's democratic experience, and by extension, the political system. The Nigerian state responded with several measures, including the deployment of military troops in what is known as "Operation Python Dance II" (or Egwu Eke II) as part of measures to cope with the movement's activities. The paper observed other measures of repression adopted by the state and how the activists have changed or adapted their responses to state repression. The paper also observed that these measures have had several consequences on the resilience of the activists.
\end{abstract}

Keywords: neo-Biafra, Operation Python Dance II, Activists' Resilience, Coercion, Nigeria

\section{Introduction}

Six years after her independence from Britain, the Nigerian state began to show her fragility and soon found herself engulfed in internal contradictions taking roots in her multi-ethnic nature. As a result of lack of cohesion among the dominant social class or ruling class, like many African post-colonial states, the military took over state institutions from the nationalist leaders to the relief of many people. But the military that took over from these politicians soon began to show they were not the solutions to the multitudinous challenges facing the country (Siollun, 2009). A year later, a bitter Civil War (1967-70) soon broke out when the former Eastern Region (dominated by ethnic Igbos, one of Nigeria's three main ethnic groups) declared itself "Republic of Biafra" out of Nigeria (Madiebo, 1980, Achebe, 2012). Despite 
the suppression of the Biafran movement in 1970, the agitation for a sovereign state of Biafra still lingers on even in a more democratic Nigeria. In any case, these two events (the January 151966 military coup and the Civil War) have shaped Nigerian politics ever since.

Consequently, the neo-Biafran movement, a regrouping of some Nigerians of ethnic Igbo origin, claiming to be actually Biafrans and not Nigerians. The movement has two large organisations, the Movement for the Actualization of the Sovereign State of Biafra (MASSOB) and the Indigenous People of Biafra (IPOB) dedicated to this cause.

This paper, therefore, analyses the repression of neo-Biafran movement under a democratic administration in Nigeria. The movement started at the inception of democratic dispensation or the Fourth Republic in 1999 has received massive media attention triggering massive support and sympathy among many people from two of Nigeria's six geopolitical zones (South-South and South-East) while also triggering a massive increase in agitations for a sovereign state of Biafra alongside the creation of allied groups and the strengthening of already existing ones. The movement seems to be on agenda of the ruling class with several politicians (especially from these earlier mentioned geopolitical zones) under pressure to make categorical statements about the Biafran cause.

The Nigerian government responded to these new challenges with varying levels of repression including deploying full scale military operation known as 'Operation Python Dance' (Egwu Eke II) to curtail the movement in 2017 and adopting new regulations to ensure public order that seem to curb the rights of these groups to protest and publicly express themselves.

This paper is based on the following research questions:

i. What are the overt and covert repression measures adopted by the Nigerian state to curb the perceived threats from the neo-Biafra activists?

ii. How did the activists respond to the repression measures?

iii. What are the consequences of these measures on the movement?

These questions will be analyzed using content analysis as a research method. This paper hopes to fill a research gap that seems to have escaped rigorous academic inquiry because there is a current tendency for scholars to overlook or empirically under-researched this aspect of social movement.

Cunningham $(2003,2004)$ makes a distinction between the measures of repression and functions of particular state actions. Based on his classifications or typology of repressions, Cunningham recognises the role(s) or responsibilities of the State to maintain "law and order". But in what circumstances or at what points are state actions "justified" in relation to social movement activities? On her part, Jennifer Earl (2003, 2004) developed a more complex typology. Earl (2003: 48, 49) distinguishes between State power to deploy 'coercion' and 'channeling', with the latter defined as 'more indirect repression, which is meant to affect the forms of protest available, the timing of protests, and/or flows of resources to movements'. The latter is what Garcia called "soft repression" (García, 2013). She further identified three groups of repressors which include: first, state agents with tight ties to the ruling class or elites; second, state agents with loose ties to the ruling class or elites; and third, non-state agents with passive support of the ruling class or elites. While Earl seems to have developed 
these typologies in order to facilitate theory building in social movements scholarship, Boykoff (2007: 285) developed a typology is more focused on repression whereas some of the 'unobserved' forms of 'channeling' she proposes - such as US tax laws that provide tax relief for non-profit organizations - swerve away from disruptive state repression and toward facilitative legal structures, or 'channeling'. While measures such as direct 'coercion' are more common during military or authoritarian regimes, other measures like 'channeling' are more likely to be used in a democratic era. All these measures have varying effects on the activists themselves.

This paper, therefore, will argue that main effects of whatever the form of repression studied stems from the obvious deterrent effect the state intends to achieve in adopting the measure(s) from the beginning. In addition, the paper also adds a new case study, neo-Biafran movement and the repression measure 'Operation Python Dance' (Egwu Eke II) in the study of measures of repression in social movement literature. In addition, this paper studies the role of important state institution like the military, whereas Earl (2003) sidesteps the repressive role this crucial institution sometimes plays in quelling social movement activities especially in developing countries.

\subsection{The State, Repression, and Social Movement: A Theoretical Exploration}

Anisin (2015: 17) noted that there is "...greater complexity in the relationship between state repression and dissent that has thus far been admitted and theorized." But, scholars seem to agree that Western democracies tend toward adopting "soft repression" measures in dealing with the threats of social movement activities by adopting measures like negotiation, rather than outright coercion (della Porta \& Diani, 2006). Western scholars also seem to be unanimous that measures like "coercion" tends to be used only in authoritarian regimes, and rarely in democratic states (Hlaing, 2007; Mix, 2014; Menoret, 2016; Anisin, 2015). Weber (1946) is quoted to have made a case for state repression of social movement when he referred to the state as the organization with a "monopoly on violence." What the expression "monopoly of violence" entails the fact that the state has the license for the successful and justifiable use of coercion or physical force or repression on any individual or groups of individuals within any area it administers. Repression can be in soft or coercive measures.

Anisin (2015: 23) argues that repression is a "central function of the state and part of its monopoly of violence." This may stem from the fact that Alex Tocqueville has earlier postulated that there seems to be a constant opposition between State and social movement objectives and strengths (Kriesi, 2004). He hypothesized, from his observations of the United States and France, that there is an inverse relationship between the strength of social movements and those of the state. In any case, other things being equal, when the state was weak and social movements are strong (as he observed in the United States) and the state will have little or no option that to cope and tolerate series of movement-generated protests and threats. On the other hand, when the state is strong, there will be weak social movements as he observed during the French Revolution and that will mean constant state (of violent) repression of social movement activities.

While Tocqueville's strong-weak/state-social movement hypothesis appears tenable on the surface, evidence suggests the contrary. The state "tend to rely more on" writes Boykoff (2007: 303) even in liberal countries like the US, varying "forms of repression" as a means of 
guaranteeing social order. Boykoff (2007: 287) classifies the "mechanisms of repression" the state adopts in the United States as the following: (1) Resource Depletion, (2) Stigmatization, (3) Divisive Disruption, and (4) Intimidation. He further notes "These four mechanisms coexist and overlap as they alter the organizing premises of the transactions between social movements, the state, the mass media, and the general public." A critical look at these four "mechanisms" or measures, shows that inherent all sovereign states contain varying measures for coercion; any observed difference(s) is a question of degree, not of kind (Fukuyama, 2011). This is why, Anisin (2015) writes that some authoritarian states like Iran and North Korea, "have a much greater capacity to carry out repression and take measures of social control than others."

Gamson and Meyer (1996) and Diani (1996) maintain that social movement activists must hold the belief that opportunities exist for them to blame the state or the system for the problem(s) before engaging in protests. In looking for this opportunity- for the state to respond to protests with repression- their perceptions of state response may be particularly influenced, for instance, by its more dramatic manifestations, such as repression, causing the "soft" measures, such as negotiation, to be overlooked (della Porta, 1996). It is, therefore, important to understand activists' perceptions of the available opportunities as seen through the lenses of state repression (McAdam, McCarthy, \& Zald, 1996).

One of the justifications for the use of state coercion to curb the threats of social movement activists is that they sometimes resort to the use of violence or become national security threats which the state has a responsibility to protect (Weber, 1946). But the use of violence comes with several limitations. First, violent reactions from movement activists often cause an escalation in state repression and isolate the activists from their non-activists' supporters hence losing the vital battle of a favourable public opinion which the movements often need during the heat of extreme repressions. Second, it tends to polarize the conflict transforming to what Tarrow (1994: 104) sees as "relations between challengers and authorities from a confused, many-sided game into a bipolar one in which people are forced to choose sides, allies defect, bystanders retreat and the state's repressive apparatus swings into action." Repression does not need to be manifested in the form of physical violence. It can as well be psychological such as what Boykoff (2007) calls "Stigmatization", isolation, or in some cases, intimidation of the activists with the state denying the movements' access to funding. Having explored these differences, this paper does not intend to inquire into the philosophical undertones, arguments or the moral (un)justification of state repression of social movement activists, but rather the focus here will be placed on the state's deployment or adoption of repression measures within the contexts of state-social movement relations by analysing effects of the measures of repression on neo-Biafran activists with the launch of 'Operation Python Dance' by the Nigerian state and their consequences.

\subsection{The Political Context and the Neo-Biafran Movement}

To properly appreciate the degree to which state repression and neo-Biafran activities operated we must realise the importance of the political contexts within which the movement functions. This is because no two contexts are exactly the same. Hence the seemingly unending debate between particularists and univerisalists (Fominaya \& Wood, 2011: 6). These contexts also determine both the measures for and reactions to, repression (ibid). 
There have been several explanations for the rise of neo-Biafran agitations in recent times with ethnic bigotry, exclusion and competition (Owen, 2016), economic deprivations (Okeke 2016; Gurr, 1970), the inter-generational conflicts between the "old and young Igbos" (Onuoha, 2014) and state repression activities (Onuoha, 2012; Ukiwo, 2009). The first explanation deals with inherent political competition existing among ethnic groups in Nigeria in the struggle for state resources. Owen (2016) maintains that Igbo ethnic faction of the Nigerian political elite group feels "excluded from power" with the loss of President Goodluck Jonathan in the 2015 presidential election whom the south-east gave massive support hence fuelling the current wave of agitations. This view was also echoed by Philip U. Efiong, the son of the ex-Biafran second-in-command during the war, late Major-General Philip Efiong, that the rise of neo-Biafran movement "is a consequence of feeling excluded" (Efiong, 2017). The second explanation deals with economic deprivations. This explanation seems to agree with Muller and Jukam (1983) arguing that people tend to take part in protests because they "are discontented about something." It is claimed that the current rise of neo-Biafran activities is the "political expression of economic frustrations of young people." (Ibeanu, Orji, Iwuamadi, 2016: 6). The third explanation is about the "clash" between two generations- the old (who witnessed and participated during the Civil War) and the young (who were born after the War). This position was canvassed in a study by Onuoha (2014) who contends that the rise of neo-Biafran activism can be accounted for by the seeming suspicion between the more active and radical younger generation (represented by groups like IPOB and MASSOB) and the conservative older generation (represented by Ohanaze Ndigbo). He noted that an attempt to seek understanding between these two "these opposing views have completely collapsed on many occasions and have sometimes led to open threats of attack on prominent Igbo elites by MASSOB members..." (Onuoha, 2014: 18). The fourth explanation deals effects of the attempts by the Nigerian state to suppress the movement physically, psychologically and violently. In the study carried out by Godwin Onuoha captures this position. Onuoha (2012: 29) noted that the neo-Biafran movement gained momentum from the rising repressions from the Nigerian state commencing from the return of civil rule in 1999 which "has been marked by interstices of democratic gains and unprecedented levels of violence, tension and insecurity." He argued that the Fourth Republic "opened up the public space and unleashed a host of hitherto suppressed and dormant ethnic forces in the country" (Ibid). In another study, Ukiwo (2009: 11) argues that "state violence, rather than cultural divisions, that triggered the secessionist attempt of Biafra and continues to foster ethnic nationalism in contemporary Nigeria." According to him, the rise in the clampdown of neo-Biafran activists in several locations in the south-east was responsible for the resurgence.

Despite the gaps in the current explanations which their tendencies for painting "incomplete picture of Biafra separatism" (Ibeanu et al., 2016: 7) this researcher goes with the third and fourth explanations because: first, they into the scope of this study, the neo-Biafran movement, which (in the researcher's opinion) dates back to 1999 with the formation of the Movement for the Sovereign State of Biafra (MASSOB) a group that gave birth to others like the Indigenous People of Biafra (IPOB). Second, they are today the most popular positions that can be supported by credible data. In this case, suppression and repression of the 
movement. Our perspective of neo-Biafra movement therefore stems from the fact that Chukwuemeka Odimegwu Ojukwu (ex-Biafran warlord) since his return to Nigeria in 1982 (12 years after the War) has maintained that the existence of Biafra as a political reality was in the past which is why he appeared distant from the methods of the neo-Biafrans calling his own "Biafra of the mind" (Adindu, 2012). Third, though like other explanations, they place much "emphasis on the period since 1999" (Ibeanu et al., 2016: 7) they have must relationships with developments since the colonial and post-colonial experiences. Fourth, they are the most empirically understudied and underdeveloped explanations in the contexts of neo-Biafran literature.

Before we go ahead, we need to give the following backgrounds on the characters that formed the Nigerian political class after a military to civilian transition in 1999. The first were retired military men (e.g ex-military head of state, Olusegun Obasanjo) who either held government positions or played some roles during the civil war and were elected on different political platforms on the return to democracy. The second were civilians (e.g All People's Party, APP's presidential candidate, Chief Olu Falae and Senator Arthur Nzeribe, elected into the Senate on the platform of the All People's Party, APP) who worked with the military government in different capacities but now holding government positions. The third group of persons were those who fought against the military governments that either went underground, went on exile or were imprisoned participated in protests against military dictatorship but still carry the burden of repressions they suffered during the military regimes. To this group, we can include the National Democratic Coalition (NADECO) activists who were elected Governors of different states of the federation. This background is important to our understanding of how the "military culture" was transferred into the several repression measures adopted by the state under civilian administrations in the Fourth Republic.

Onuoha (2014: 21) notes that the return to civil rule in 1999, after several years of military dictatorships, brought relative degrees of relaxed "repressive nature of the state" and unfortunately "opened up a ... future vector for alternative social and political projects in the country." Though many ethnic self-determination groups largely went underground during the military regimes, the newly found constitutional freedoms of expression and association led many organisations like the Oodua People's Congress (OPC) then led by Dr. Frederick Fasheun and the formation of the Movement for the Sovereign State of Biafra (MASSOB) in September 1999 by an Indian-trained lawyer, Chief Ralf Uwazuirike effectively beginning a new wave which we call the neo-Biafran movement.

Uwazuirike, a People's Democratic Party (PDP) member who supported the party's presidential candidate and former military head of state, Chief Olusegun Obasanjo, in 1999 felt disappointed when President Obasanjo made federal appointments leaving out Igbos who voted overwhelmingly for him (Onuoha, 2014).

MASSOB emerged as a group that support the principles of "pacifism and non-violence", its objectives which include the actualization of a sovereign state of Biafra saw it often clashing with Nigerian state institutions like the police and the military (Onuoha, 2014). These clashes with the authorities have led to several arrests (including Chief Uwazuirike) and loss of lives (Human Rights Watch, 2005). When the activities of these groups began getting out of control, President Obasanjo ordered their disbandment in July 2000 (Agbu, 2004: 23). 
Despite the President's directive, MASSOB continued its activities in the south-east.

Clashes between the police and MASSOB members continue, despite being declared illegal following a campaign organized by MASSOB to boycott the population census in 2006 apparently resulted in dozens of deaths, including a few police officers (PANA 23 Mar. 2006). This reportedly infuriated President Olusegun Obasanjo who reportedly ordered the movement to be "destroyed" (Ekwe-Ekwe, 2006).

The antagonistic attitude of the Nigerian state to neo-Biafra movement and its activities continued in varying forms even when "civilian" Presidents Umoru Musa Yar'Adua and Goodluck Jonathan were elected in 2007 and 2011. For example, even though he was largely supported by Igbos, the Jonathan government initially refused to issue certification for a pro-Biafran movie which is based on Chimamanda Adichie's Half of a Yellow Sun when the movie has been aired at several countries including Toronto International Film Festival in 2014 (Bandele, 2014). The government's official explanation for the incident is that it found some scenes in the movie "objectionable" but later gave approval for the movie to go live after the directors edited the objectionable scenes and the government "expressed their satisfaction with the edits" (BBC News, 2014).

Also, in March 2014, members of the militant group Biafra Zionist Federation (BZM) a breakaway group from MASSOB took control of the Enugu State Government house for about 4 hours and erected the flag of Biafra at the entrance of the house. He gave Nigerians living in Biafran territory an ultimatum to vacate their land before March 31, 2014, or face the bloodbath that will come afterwards (Edike, 2014). The BZM leader, Mr. Benjamin Onwuka and 12 members, later were rounded up after a failed attempt to seize the Enugu State Broadcasting Service, ESBS and tried for treason.

In the heat of severe state repressions on these groups, several neo-Biafran groups began breaking into factions. The election of another ex-military head of state, General Muhammadu Buhari, as president in 2015 provided the much-need catalyst for the rise of a new wave in the neo-Biafran movement, Nnamdi Kanu of the MASSOB-owned Radio Biafra broadcasting from London. Kanu (who earlier fell out of favour with Uwazruike) using the instrumentality and growing popularity of the Radio quickly formed what is now known as the Indigenous People of Biafra (IPOB), first as an announcement on Radio Biafra in 2012 but became operationally effective in 2014. It became "operationally effective" by which we mean the organisation set up state institutions and ask "Biafrans to take directives from the Council of Elders of the Indigenous Peoples of Biafra" (Okute, 2015: 22). The formation of IPOB will, as we will later come to see, change the cause of neo-Biafran movement in Nigeria especially in the area of Nigerian state repressions of social movements.

\section{Methodology}

The primary methodology adopted for this study is content analysis. This involves analyses of "volume of texts collected, identifies and groups categories together and seeks some understanding of it" (Bengtsson, 2016: 8). This involves the review of news published on two daily newspapers in Nigeria (The Sun and The Vanguard) for the "peak" periods of neo-Biafran mentions from- July 2014 to September 2017 in order to draw out relevant information. The open coding which ensures the researcher to present his finding in the forms 
of "themes, categories/sub-themes, and sub-categories/subheadings, as a table to allow the reader to get quick review of the results" (Bengtsson, 2016: 12). Content analyses of both newspapers on the issue of research generated 199 mentions condensed into 5 units of analysis or themes after coding.

The researcher also used Google Trends to generate data. This involves typing of keywords such as "Biafra", "Operation Python Dance II" "Egwu Eke II", "MASSOB", "IPOB", "Nnamdi Kanu" "Igbos" on Google Trends, a platform launched by Google Inc, to show, according to Wikipedia "how often a particular search-term is entered relative to the total search-volume across various regions of the world, and in various languages". This then gives the researcher the idea of the number of searches for the individual words and the timeframe for such as shown in Figure 3. These trends also gave the researcher the top posts mainly from neo-Biafran activists (12 each for Facebook and Twitter during the period under review, 2014- September 2017 in Figures 1 and 2 below) which formed the periodization of the research. These data were analysed using Statistical Package for Social Scientists (SPSS) version 20 .

\section{Figure 1}

\section{Facebook Posts}

\begin{tabular}{l|l|}
\hline 1 & Prof. Soyinka on \#Biafra: \#Biafra is an ideology that cannot be defeated! \\
\hline 2 & This Biafra amateurish movement is so stupid and childish \\
\hline 3 & IPOB releases prototype of Biafra govt \\
\hline 4 & Operation Egwu Eke in Igbo Land \\
\hline 5 & Operation Python Dance must stop, it's causing a whole lot of havoc, Unrest and chaos \\
\hline 6 & Operation Python Dance in southeastern Nigeria, Shame onto Nigerian Army \\
\hline 7 & $\begin{array}{l}\text { Buhari finally listen operation python dance ll to be withdrawn, let all parties sue for peace. } \\
\text { Humanity should be primal }\end{array}$ \\
\hline 8 & $\begin{array}{l}\text { We need to be united... we can't follow in the footsteps of the UK" Two young women from UK and } \\
\text { Nigeria share their thoughts on Brexit and Biafraexit }\end{array}$ \\
\hline 9 & $\begin{array}{l}\text { If anyone has a video or written article of Obasanjo calling for Nnamdi Kanu's assassination please } \\
\text { kindly share with me. Maybe it's true, but I'm yet to find any evidence of such from any credible med... }\end{array}$ \\
\hline 10 & GOVERNMENT OF NIGERIA versus NNAMDI KANU: AN ABSURD DEVELOPMENT. \\
\hline 11 & We won't be deceived by 2 $2^{\text {nd }}$ Niger Bridge- MASSOB \\
\hline 12 & MASSOB gives August as deadline for Igbo mass return \\
\hline
\end{tabular}


Figure 2

Tweets

\begin{tabular}{|c|c|}
\hline 1 & $\begin{array}{l}@ \text { realDonald Trump } \mathrm{Mr} \text { President, Biafra is united in common destiny with Israel. The } \\
\text { people of Biafra have died for you on } 20^{\text {th }} \text { January } 2016 \text { on a rally in solidarity with you } \\
\text { on your inauguration as the } 54^{\text {th }} \text { pres. Of the USA }\end{array}$ \\
\hline 2 & $\begin{array}{l}\text { If Kanu IPOB ever appeared he II rot in Jail. He h'd bera remained hidden. \#IPOB \#MASSOB } \\
\text { \#Anambra }\end{array}$ \\
\hline 3 & $\begin{array}{l}\text { Please become aware of \#biafra, \#massob, and the recent history of the Nigerian Civil war, to } \\
\text { understand what is being played as a political football in America }\end{array}$ \\
\hline 4 & $\begin{array}{l}\text { As much as I do not like the use of force by the military, but I don't like \#IPOB and \#MASSOB } \\
\text { people ringing the bells of war }\end{array}$ \\
\hline 5 & $\begin{array}{l}\text { Operation Python Dance has danced away the terrorist called IPOB, Nnamdi Kanu is a hiding } \\
\text { leader. What a Shame!! }\end{array}$ \\
\hline 6 & $\begin{array}{l}\text { People killed in Borno, Buhari will not command the army to take their useless operation } \\
\text { python dance, to Borno to fight Boko Haram }\end{array}$ \\
\hline 7 & Self-determination is a universal phenomenon \#Biafranexit \\
\hline 8 & Biafran's blood was no spilled for restructuring, Biafraexit that's all @AsoRock \\
\hline 9 & $\begin{array}{l}\text { NorthEast: Lafiya Dole, SouthEast: Egwu Eke, SouthWest: ?? Pondering on the appropriate } \\
\text { Yoruba interpretation for 'Crocodile Smile' }\end{array}$ \\
\hline 10 & Nigerian Army announces the end of operation EGWU EKE II \\
\hline 11 & $\begin{array}{l}\text { When I said 'koboko' (whips) can reset brains, some thought I was joking. Thank God Python has } \\
\text { stopped dancing today. Egwu Eke II }\end{array}$ \\
\hline 12 & $\begin{array}{l}\text { Exercise Egwu Eke II, also known as Operation Python Dance has finally come to an end. The } \\
\text { Bastard has been bastardised. }\end{array}$ \\
\hline
\end{tabular}

\section{Figure 3}

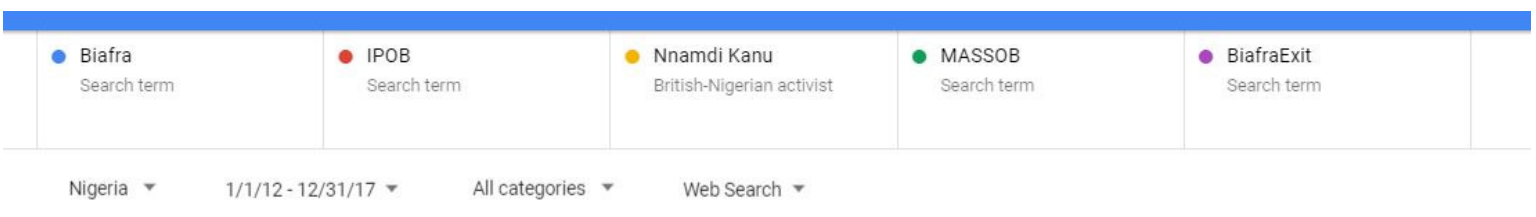

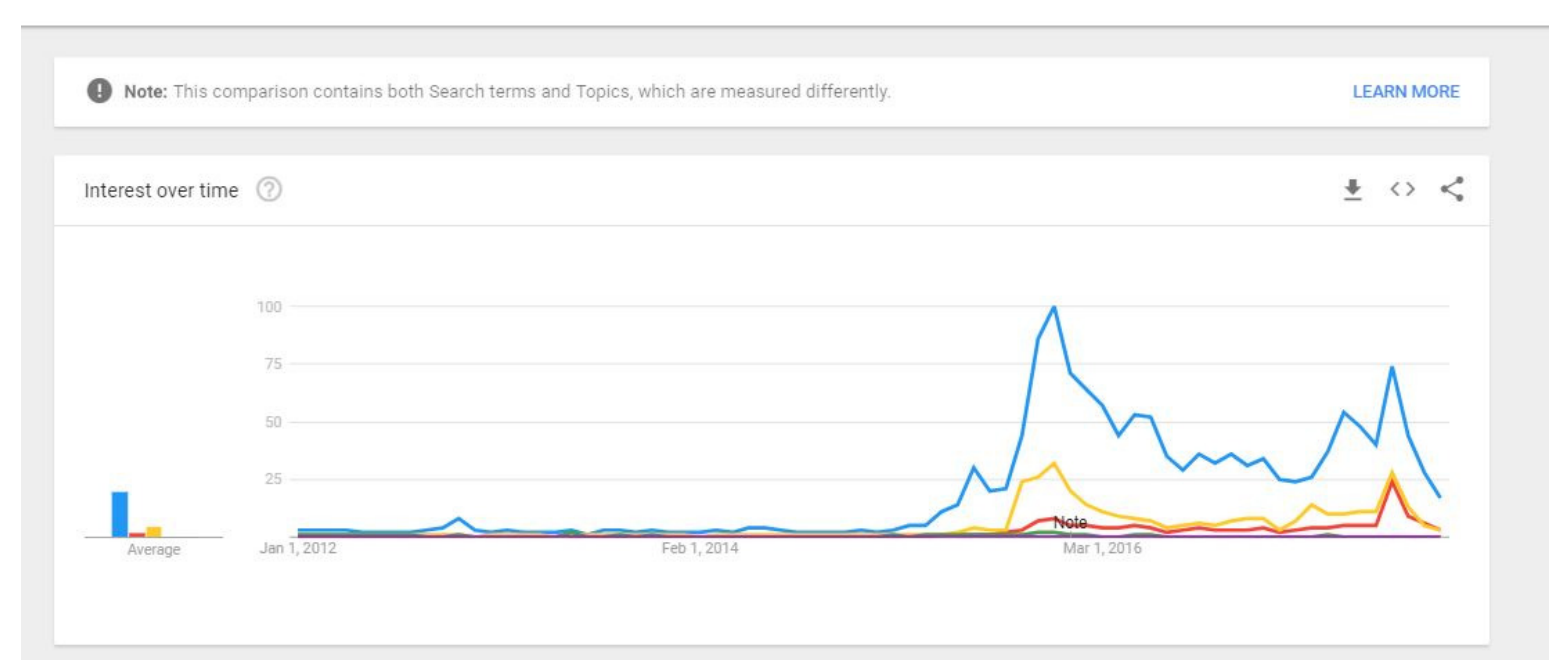




\section{Analysis and Interpretation of Data}

This study is based on 199 references or news reports from two national newspapers (The Vanguard and The Sun). The distribution of the issues are as shown in the table below:

Table 1. Source of information

\begin{tabular}{llll}
\hline Source & & Frequency & Percentage \\
\hline & The Vanguard & 96 & 48.2 \\
& The Sun & 103 & 51.8 \\
& Total & $\mathbf{1 9 9}$ & $\mathbf{1 0 0 . 0}$ \\
\hline
\end{tabular}

Table 2 shows that The Sun covered more (103 referrals or 51.8\%) while The Vanguard covered the remaining (96 or $48.2 \%$ ). In all, the distribution and coverage of the issue were fairly balanced between both newspapers.

The locations of incidence are also important when covering issues like neo-Biafran movement. The reportage of news of the activities of the movement shows that most of the events $(58.8 \%)$ took place in Nigeria's south-east geopolitical zone which comprises five states: Abia, Enugu, Anambra, Ebonyi, and Imo. States like Delta and Rivers with a large population of Igbos has $7.5 \%$ of the events taking place in their territories even though they are geographically in the south-south geo-political zone of the country. Two states, Anambra $(24.15 \%)$ and Abia (17.1\%), led in the coverage of the reports. Apart from the fact that these states have the two largest commercial cities in the south-east (Onitsha and Aba) which provide fertile grounds for the neo-Biafra activists to thrive partly due to the high number of unemployed young people (Ibeanu et al., 2016, Oduah, 2017), the IPOB leader, hails from Abia state.

Abuja having 16.6\% after Abia can be explained with the treason trial IPOB and MASSOB activists at different times in Abuja and the fact that it is the nation's capital.

States like Lagos, Edo, and Cross River took $2.5 \%$ of the activities since they are outside the Igbo-dominated states. Some neo-Biafran activities took place in other places like in the United Kingdom, where Nnamdi Kanu's Radio Biafra has been broadcasting from. Figures 4 and 5 from Google Trends also seem to confirm this data.

Table 2. Location of incident(s)

\begin{tabular}{cll}
\hline State/Location & Frequency & Percentage \\
\hline Abia & 34 & 17.1 \\
Abuja & 33 & 16.6 \\
Anambra & 48 & 24.1 \\
Bayelsa & 5 & 2.5 \\
Ebonyi & 5 & 2.5 \\
\hline
\end{tabular}




$\begin{array}{lll}\text { Enugu } & 21 & 10.6 \\ \text { Cross River } & 1 & .5 \\ \text { Rivers } & 11 & 5.5 \\ \text { Lagos } & 1 & .5 \\ \text { Imo } & 9 & 4.5 \\ \text { Others } & 23 & 11.6 \\ \text { Edo } & 3 & 1.5 \\ \text { Delta } & 4 & 2.0 \\ \text { London, UK } & 1 & .5 \\ \text { Total } & \mathbf{1 9 9} & \mathbf{1 0 0 . 0}\end{array}$

\section{Figure 4}

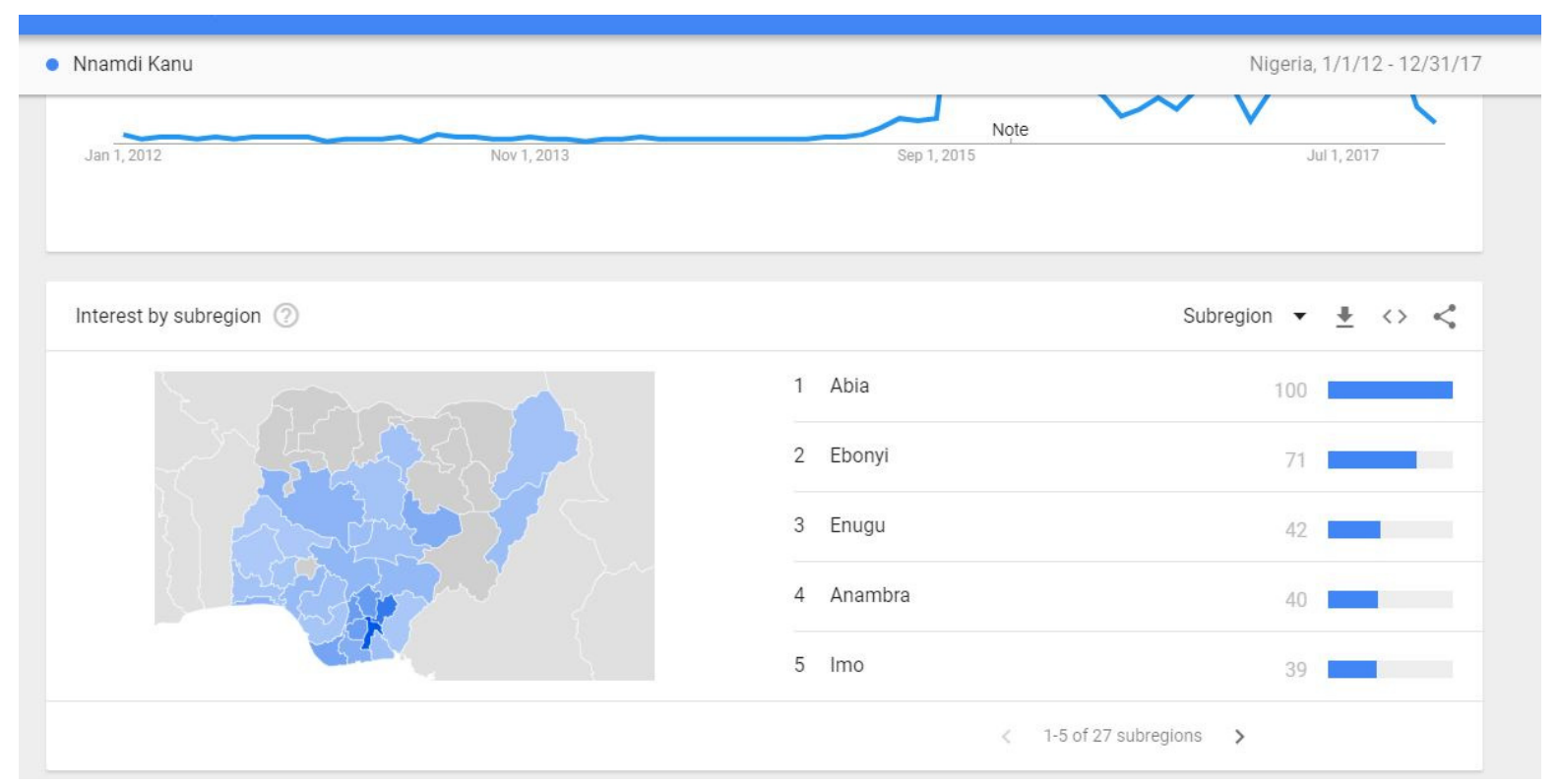




\section{Figure 5}

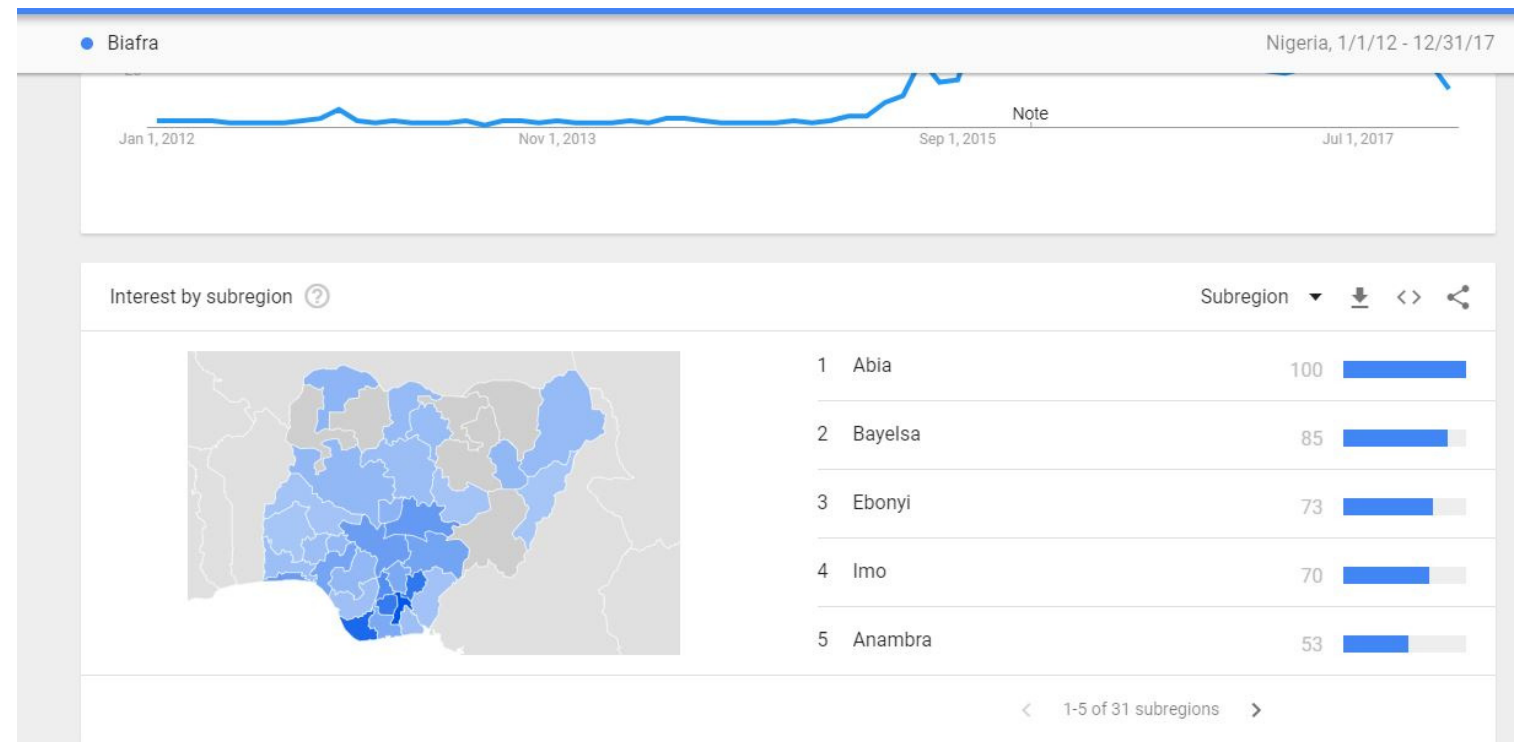

Specifically, five units of analysis are generated. The content analysis of the newspapers gave rise to the following themes, variables or categories dealing with measures of state actions or repression, movement's reactions, and consequences:

i. Coercion

ii. Activists' Resilience

iii. Judicial Process/Trial

iv. Isolation \& Stigmatization

v. Political Action(s) \& Involvements

The themes are summarised into three main issues relating to our research questions:

i. The Measures of state repression;

ii. The reactions of Movement activists; and

iii. The Consequences of repressions on the movement

Table 3. Breakdown of variables

\begin{tabular}{lll}
\hline \multicolumn{1}{c}{ Variables } & Frequency & Percentage \\
\hline I. Coercion (51 or 25.6\%) & 17 & \\
Arrest of activists & 10 & 8.5 \\
Deployment of troops & 3 & 5.0 \\
Declaration of curfew & 3 & 1.5 \\
Terrorist treatment for activists & 13 & 1.5 \\
Killing of activists & 4 & 6.5 \\
Forceful dispersal of protesting activists & & 2.0 \\
\hline
\end{tabular}


Invasion of private properties

II. Activists' Resilience (106 or 53.2\%)

Condemnation of State Repression

Boycott of elections .5

Continuation of protests 19.1

Confrontation with security agencies

Discontinuation of negotiations with the state

Cracks within the movement

Condemnation of movements' proscription

Demand for the release of activists

Denial of criminal allegations

Negotiations for activists' release

Demand for investigations into killings of ${ }_{1}$

Taking of hostages/terrorist acts

Commencement of "new Republic"

Harassment and embarrassment of public

officials

\section{Isolation \& Intimidation of Movement (16 or $8.04 \%$ )}

Prohibition of Movement's activities

Blocking of Sources of group's funds

Disappearance of activists

Threats to protesters with physical force

Police summon of activists

Politicians deny sponsoring movement

IV. Political Action(s) and Involvements (16 or $8.04 \%$ )

Igbo leaders' meeting with President Buhari ${ }^{1}$

over tension created by activists

Demand for Inquiry into killings of activists $\quad 1 \quad .5$

Politicians/Leaders' condemnation of killings of ${ }_{1}$ activists 
Politicians/Leaders' demand for the release of 4 activists

Political advice to embrace dialogue

Activists' demand for resignation of state 2 officials

Meeting with political leaders

State Inquiry into killings of activists

1

2
Activists demand restructuring of the federation 3

V. Judicial Process/Trial (11 or 5.5\%)

Activists' threat to sue the state over killings

Trial of activists

Release of activists

Court Injunction against activists
.5

.5

1.0

\section{5}

.5

1.5

2.0

1.5

Total

100.0

\subsection{Interpretation of Data on Research Question (i) - Overt and Covert Repression Measures}

Three of the positions deal with the repression measures. Three variables I, III, and V provide the key to answering this question.

Analysis of Variable I: Coercion

Variable I deals with the state's direct use of force on the neo-Biafran activists. The variable accounts for 51 out of 199 items $(25.6 \%)$ of our sample frame. The measures include several arrests and detention of the activists, including the IPOB leader, Nnamdi Kanu and some of his comrades in October 2015. The arrest of Kanu and his supporters led to massive demonstrations to demand his release. These demonstrations, however, did not halt the waves of arrests as another 59 suspected IPOB members were arrested by security agencies in the heat of the deployment of troops under the Operation Python Dance II in 2017 according to The Vanguard (Gabriel, Agbakwuru, Yakubu, \& Agbo, 2017). The arrests of neo-Biafra activists, however, did not start with Kanu or the IPOB era. During President Olusegun Obasanjo administration, infuriated by the rising profile of MASSOB, the state began a clampdown on the group and its leader. On many occasions, its leader, Uwazuruike and supporters, were arrested and detained on various charges (Ezea, 2017).

In addition to the arrests of neo-Biafra activists, the state also deployed its most potent instrument of violence- the military- in her attempts to curb the activities of the activists. Despite the already militarised south-east region where the state had launched "Operation Python Dance I" in the five South-East states in November 2016, the Nigerian military began the Operation Python Dance II to "tackle such security problems such as armed bandits, cult 
clashes, communal clashes, kidnappings, cultism, farmers-herdsmen clashes, and violent secessionist agitations, in the South-East zone of the country" (Daily Trust, 2017a). The deployment of troops was what the IPOB and other neo-Biafra groups viewed as "show of force" by the state in curbing its activities.

While this remains in the realms of speculations, the state might have considered the military option when IPOB reportedly inaugurated the "Biafra Security Service" with its leader "inspecting what can be described as a guard of honour" a month earlier (The Punch, 2017).

During the period of Operation Python Dance II, the Abia state Governor, Dr. Okezie Ikpeazu, declared curfew as parts of efforts to reduce the rising casualties resulting from violent clashes between the military and IPOB activities. This dangerous twist led to the killing and disappearance of several activists. In 2016, during an event organised by IPOB in Onitsha, Anambra state, the Nigerian army, according to Amnesty International, "gunned down unarmed people" (Amnesty International, 2016b).

As a result of the frequent clashes between the activists and the security agencies, the Nigerian military declared IPOB a terrorist organization. It justified its action with the group's formation of state institutions, like the Biafran Secret Service (BSS) and "possession and use of weapons" (Kazeem, 2017). Declaring the group a "terrorist organisation" meant their members could thenceforth be treated as terrorists when arrested by security agencies (Gabriel, Agbakwuru, Yakubu, \& Agbo, 2017).

Another aspect of this variable is the forceful dispersal of activists' protests. Several neo-Biafra activists' protests have seen several attempts at disrupted either through intimidation or by the show of force on the part of the security agencies. A good example of this was the IPOB's August 2017 Port Harcourt protest where the police were said to have "chased them [IPOB members] away as they all fled into different directions" (Akasike, 2017). Also, according to Amnesty International, the Nigerian security agencies have killed "at least 150 members and supporters of the pro-Biafran organization IPOB (Indigenous People of Biafra) and injured hundreds during non-violent meetings, marches and other gatherings. Hundreds were also arbitrarily arrested" between August 2015 and 2016 (Amnesty International, 2016a: 5).

Another demonstration of the use of coercion by the Nigerian state is the invasion of private properties of the neo-Biafra activists by the security agencies. In 2012, officers from Nigeria Police, Achalla Division, Awka North LGA raided the offices of MASSOB and carted away items belonging to the group (Onuchukwu, 2012). Also, during the carnage at Nnamdi Kanu's house in the heat of Operation Python Dance II, IPOB alleged that security agencies "looted Nnamdi Kanu's family house at Afaraukwu, Umuahia in Abia State" (Chiedozie, 2017b). Acts such as these demonstrate extreme, crude use of coercion to force the activists into submission.

Analysis of Variable III: Isolation \& Intimidation of Activists

Variable III deals with the state's use of intimidation, isolation, and stigmatization to curb the activities of the activists. This variable accounts for $8.04 \%$ of our units of analysis. In addition to the state's use of coercion, this variable seems to complement other measures adopted by the state. The state issued several threats (especially President Buhari's famous 
"national red lines" speech after he officially resumed from his medical leave in August 2017) to the activists in a bid curb their resolve. On his return, the President warned, "I was distressed to notice that some of the comments, especially in the social media have crossed our national red lines by daring to question our collective existence as a nation," (culled from Al Jazeera, 2017).

One of the clear indications that the movement is losing its steam was when politicians from the south-east region began denying sponsoring the movement, especially the IPOB. The governors of the five states under the leadership of Ebonyi state Governor, Chief David Umahi, also distanced themselves from the allegations that they are working against the federal government with their tactic support for neo-Biafran groups (Okutu \& Agbo, 2017). The politicians later proscribed the IPOB and its activities in the region after they said they remained "commitment to one united and indivisible Nigeria" (Channels Television, 2017). In justifying the proscription of the group's activities, the Governors said the group's leader, Nnamdi Kanu, was "gradually losing control of the situation and his members" hence the need for them to "wade in to prevent further bloodshed" (Eze, 2017).

With the obvious decline in the IPOB activities coupled with the disappearance of several activists including its leader, Nnamdi Kanu, the federal government began taking several steps (including diplomatic actions) to block the group's flow of funds (Daily Trust, 2017b).

Other measures of intimidation also include summons of activists by security agencies. On 22 August 2014, the Imo State Police Command summoned MASSOB leader, Ralph Uwazuruike, to explain the disturbances by MASSOB members that led to the death of four people. The police gave the activists " 24 hours to report to the police to explain the circumstances that led to the crisis or be declared wanted" (Daily Trust, 2014).

Analysis of Variable V: Judicial Process/Trial

Variable $\mathrm{V}$ deals with how the state used the Judiciary as a measure to curb the threats posed by the neo-Biafra activists. This variable accounts for 11 of our 199 units of analysis (or $5.5 \%$ ). Under a democracy, the judiciary plays the role of adjudicator of disputes. This is why the courts have roles to play in the trials of arrested activists. The arrest and later release, of Kanu and Uwazuruike of the IPOB and MASSOB respectively, show the state was not only about coercion. On 20 January 2016, an Umuahia Magistrate's Court granted bail to 26 neo-Biafra protesters previously charged with conspiracy to commit a felony and belonging to an unlawful society (The Vanguard, 2016a).

Though the courts granted many of the activists' requests, many judgements went against them. One of them was when a Federal High Court Abuja, in 2016, granted the Department of State Security an order to detain IPOB leader, Nnamdi Kanu, for another 90 days (Okakwu, 2017). Also, on 21 September 2017, a Federal High Court sitting in Abuja granted an order declaring IPOB activities as "acts of terrorism and illegality" (This Day, 2017). With judgements like these, the activists appear to be losing their confidence in the Nigerian judicial system, making them either seek justice for the killing of their comrades at the International Criminal Court for genocide (The Vanguard, 2016b) or resort to self-help.

\subsection{Interpretation of Data on Research Question (ii) - Activists' Reactions to Repression}

One of the themes deals with the reactions of the movement to repression. Variable II 
provides the key to answering this question.

\section{Analysis of Variable II: Activists' Resilience}

This variable is very significant for various reasons. First, it was the most widely reported by the two newspapers covered (covering over 53\% of the reportage of the neo-Biafra activism). Second, it gives a clue into several connections to other variables like Variable IV (which we shall analyse later). Third, it shows the resolve and determination of the activists to push on even in the most difficult circumstance(s).

From the data in Table 3, we can see that the activists continued their protests even though the security agencies were often ready to forcefully disperse them. This explains why "Continuation of protests" was reported 38 times or $19.1 \%$ of the time. Despite the repression measures, according to Voice of America, there were indications that the movement was gaining strong support among young people, many of them unemployed (Oduah, 2017).

The also activists demonstrated their resilience in the face of repression(s) using several means. The activists on several occasions demand the release of their comrades. This alone accounted for 24 out of 199 items in our units of analysis. With the arrests and detention of their comrades, the activists were very vocal in demanding the release of their colleagues at nearly every opportunity. The demand for the release of the detained activists was not restricted to neo-Biafra activists alone. In August 2016, the Organised Labour under the auspices of the National Union of Chemical, Footwear, Rubber, and Non-Metallic Product Employees (NUCFRLANMPE) called on the federal government to "find a better approach of addressing" the yearnings of IPOB and other pro-Biafra groups in a "more peaceful manner rather than force" (Ahiuma- Young, 2016).

In addition to the activists demanding the release of their colleagues, they also demanded investigations into killings of their members.

The activists' confrontations with security forces took several forms. First, in defiance of the Nigerian state, neo-Biafra activists publicly used Biafra plate numbers, passports, currencies, flags which often brings them into confrontations with state forces leading to violent clashes. On 15 March 2016, Nigerian police arrested, and "secretly killing" 20 MASSOB members with Biafran/MASSOB plate numbers (Nwaiwu, 2016).

Second, there were also reports of violent clashes where IPOB members physically attacked soldiers in Aba forcing Abia state governor, Okezie Ikpeazu, to declare the curfew in the city after violent to douse the tension (Okoli, 2017).

Third, arising from the confrontation with security agencies comes the question of hostage-taking and terror-related activities. The activists sometimes resorted to hostage taking or forcefully taking over media stations to drive home their demands. In September 2015, police arrested 18 MASSOB members for allegedly holding a parish priest hostage and forcing him to conduct mass to mark MASSOB anniversary (Daily Sun, 2015). There was also the case of Benjamin Onwuka-led Biafran Zionist Movement (BZM)'s twice unsuccessful attempts to take over both the State House and Broadcasting facility to announce "Republic of Biafra" in Enugu state (Edike, 2014).

The cracks within the movement tend to derail the resilience of the activists. In the heat of the agitation and negotiations to release IPOB leader, Nnamdi Kanu, the group itself became 
factionalized. While IPOB was insisting it would only accept "unconditional release" of its leader, another group, Reformed Indigenous People of Biafra (RE-IPOB), releases a list of some eminent personalities to lead negotiations with the federal government for the release of Kanu, and over the agitations of Biafra. MASSOB, however, described the action as "causing confusion among pro-Biafra groups with falsehoods and blackmailing" (Alaribe, 2016). Also, through its Radio Biafra, IPOB accused the apex socio-political Igbo group, Ohaneze Ndigbo that some of its officials were plotting in conjunction with president Buhari to work against its leader, Kanu, in other to undermine and divide the movement. Ohaneze denied the allegations.

The activists also took turns to harass and embarrass high profile public officials as parts of their reactions to repressions. While addressing an audience at Chatham House, London, in 2017, IPOB supporters heckled Imo state Governor, Chief Rochas Okorocha, on several occasions and one of them took to the stage to embarrass the state chief executive (Pulse, 2017). Also, some Northern groups, under the auspices of Coalition of Northern Groups, $\mathrm{CNG}$, alleged that IPOB members have concluded plans to humiliate and embarrass President Buhari for approving Operation Python Dance II when he visits the United States for the $72^{\text {nd }}$ United Nations General Assembly (UNGA) in September 2017 (Daniel, 2017).

3.4 Interpretation of Data on Research Question (iii)-Consequences of Repressions on the Movement

The effects or consequences of repression is something that is so complex and can vary according to the measure(s) adopted, state agent involved (or personality of the agent) and even location where movement activities are taking place. Booth \& Richard (2000) observe that while repressions may seek to constrain or curtail movement activism, ensure some minimal level of movements' compliance to basic social norms in developed (or Western) countries, their consequences or effects in developing countries like Nigeria are quite complex and sometimes inconsistent with such with those of Western societies. The consequences of repression measures (especially the deployment of troops under the Operation Python Dance II) adopted to cope with threats of the neo-Biafra activists may be quite early to become perceptible, but they reveal some quite interesting details. A simple analysis of Variable IV on Table 3 provides the explanation.

\section{Analysis of Variable IV: Political Action(s) and Involvements}

This variable has one of the lowest (8.04\%) in our units of analysis. Because our study's time frame ended in September 2017, that may have been the reason (or one of the reasons) for the seeming low coverage.

The consequences of the repression measures manifest in several forms:

i. Tension(s) in the polity: In the era of the already-tensed environment created by Boko Haram insurgency, the threat of neo-Biafra activists created a general atmosphere of fear especially in the South-East. The missing of the IPOB leader and the accusations and counter-accusations between the Nigerian army and IPOB over his whereabouts further adds to this uncertainty and insecurity in the region (Akwagyiram, 2017). Describing the situation in the region, Governor of Ebonyi, David Umahi said [on the neo-Biafra activists] "When you put a small fire, how far it can go cannot be controlled. The IPoB activities were 
gradually going out of control of Nnamdi Kanu. Soldiers were passing by when IPOB members started throwing stones and other objects at them and it sparked the clash between the group and the military" (Eze, 2017). This tension led Igbo leaders to meet President Buhari to "present to him some of the concerns of the South East" (Opejob, 2017).

ii. Commission of Inquiry to Look Into Killings of Activists: With increased pressure on the Nigerian government, especially from Amnesty International and other groups to look into the extra-judicial killings of neo-Biafra activists, the Nigerian army agreed to set up a Panel of Inquiry to look into several allegations of human right abuses of neo-Biafra activists among its officers. According to the Chief of Army Staff, Major-General Tukur Buratai, the "allegations [of extra-judicial killings] are not good for civil-military relations and are capable of demoralising the Nigerian Army personnel in the performance of their constitutional roles" (The Vanguard, 2017b).

iii. Politicization of the Movement: The politicization of the movement took several dimensions especially with MASSOB's involvement in party politics in the bitterly-contested 2015 presidential election. In March 2015, MASSOB members marched in several state capitals in the South-East to demand the resignation of the chairman of the Independent National Electoral Commission (INEC) Professor Attahiru Jega because of the latter's "alleged nocturnal meeting he has been having with his kinsmen ion the North." The group also alleged the chairman might favour All Progressive Congress (APC) candidate, General Muhammadu Buhari against MASSOB's favoured candidate, President Goodluck Jonathan (The Vanguard, 2015). The involvement of some neo-Biafra groups in their partisan support for a candidate during elections also manifested when it became "good politics" for politicians to simply condemn state repression, and demand the release of the activists.

$i v$. Demand for Restructuring of the Nigerian Federation: one of the fallouts of the neo-Biafra agitations is for the restructuring of the Nigerian federation. Many neo-Biafra activists echoed this points at every opportunity in 2017. Second Republic politician, Chief Guy Ikokwu said during the 2017 May-30 sit-at-home order by the neo-Biafra groups, 'We believe that Nigeria can become a nation if our act of governance is restructured with true federalism and fiscal federalism, in order to move forward with justice, fairness and opportunities to become our brothers' keeper. If we are unable or unwilling to change our illusive direction then the better choice is to remove the shackles and let the various nationalities protect their future without the present impediments.' (The Vanguard, 2017a). Also, foremost constitutional lawyer, Professor Ben Nwabueze, said that agitations by mean court litigations and violent methods cannot achieve Biafra. He backed restructuring of the Nigerian federation as the only thing that can bring about lasting solution to the Biafra question (Salaudeen, 2016).

v. Disruption of Economic and Commercial Activities: The deployment of troops, declaration of a curfew, heightening insecurity in the south-east and other measures to curb the activities of neo-Biafra activists has led to several closures of markets in commercial cities like Onitsha, Aba, Owerri which are strongholds of the activists. Daily Trust reports during the Operation Python Dance II that the action saw many people "leaving in their wake an eerie silence that is a sharp contrast to the noisy nature of the community, the Biafran 
agitators and their leaders. Because there are so few people in the community, one could stand at the entrance to the community and see the last building in it" (2017).

vi. Creation of acrimonious relationships with other ethnic groups: The state use of repression has led the activists to adopt other means of coping. One of them includes the insulting, physically (and violently) attacking and assaulting members of other tribes as it was the case with IPOB members attacking members of the Hausa community in River state after a violent confrontation with the military (The Vanguard, 2017c). This may have further aggravated the already tensed inter-ethnic acrimony where some northern groups gave Igbos living in the North the so-called "quit notice" to vacate the region before 1st October 2017 which IPOB later rejected insisting that Igbos must vacate the North and return home (Chiedozie, 2017a).

\section{Summary and Conclusion}

Though there appear to have been a decline in the movement in recent time due to either disappearance of many of the activists as a consequence of the Operation Python Dance II or as a result of the proscription of the one of the largest neo-Biafra movement groups, IPOB. Despite this, the issues raised by the agitators are still salient. While it remains a challenge to evaluate this as an effect of repression, that the activists continued their activism even after the deployment of troops in September 2017; were able to put restructuring on the front burner of political discourse; got many of their comrades released from detention; got the state to set up Inquiries to look into their demands; got the support of other groups, like the organised labour, in making their demands; and got the much-needed attention of the president to listen to their grievances all attest to the resilience of the neo-Biafra activists.

According to the data, the repression has several consequences. The resilience of the activists equally has its effects on the dimensions of the movement. The court trial of the activists raised also demonstrated the resilience of the activists profiling them on both domestic and international scenes. The state's handling of Nnamdi Kanu's (and his comrades') court trial were not done tactically. It looks like the state was hell-bent on making heroes out of a case that should simply have been just like any other trial. Military tanks, formations, media stations, a large number of armed and combat-ready policemen to accompany a few groups of activists on trial seems too much of the state's "show of force" necessitating some show of sympathy for the neo-Biafra activists.

In the case of the activists, dealing with state repression sometimes put them in dilemma. They either choose to confront, sometimes violently, the state security forces dropping their toga of "non-violence" and losing the moral and public opinion battle or continue to condemn the state's use of repression through letters to foreign embassies and international media or through the judicial process. In choosing to confront the state forces, the activists often suffer more casualties and still lose the moral battle of public opinion and the sympathy they may have from non-activists. Also, that is energy-draining for the activists who may suffer from fatigue as a result of that. This fatigue was noticed when the IPOB leader called for boycott or disruption of the Anambra state Gubernatorial election scheduled to hold in November 2017. The fact that the activists had no capacity to enforce this call since the movement cannot prevent the electoral body from conducting elections, shows a clear case of movement activists' fatigue under extreme repression. Also, while some of the groups can sometimes be 
irrationally radical and lacking creative ways to cope with state repression, others appear to be finding more political solutions in their activism under the atmosphere of fear. This may create a gap for the danger of political opportunism and charlatanism.

This study deals with the overt and covert state repression measures and their consequences on activists' resilience which is an area social movement scholars have conducted little empirical research. The relationship between the states and social movements has several dimensions is a tricky one. This is why future research may want to do a comparative research on the consequences of repression on activists' resilience in developed and developing countries and see if they have the same results. Also, further longitudinal research may be needed on this study for further empirical verifications and alternative explanations using other theories.

\section{Compliance with Ethical Standards}

Funding: The author received no funding for this work.

Conflict of Interest: Author declares that he has no conflict of interest.

\section{References}

\section{Books, Journals, and Other Publications}

Achebe, C. (2012). There was a country: A personal history of Biafra. London: Penguin Group Ltd.

Agbu, O. (2004). Ethnic militias and the threat to democracy in post-transition Nigeria Research report No. 127 Uppsala: Nordiska Afrikainstitutet

Amnesty International (2016a) Nigeria: 'Bullets were raining everywhere' deadly repression of pro-Biafra activists' Retrieved from https:/www.amnesty.nl/content/uploads/2017/02/AFR4452112016ENGLISH.pdf?x82182 on 3 April 2018

Amnesty International, (2016b, June 10). Nigeria: Killing of unarmed pro-Biafra supporters by military must be urgently investigated Retrieved from https://www.amnesty.org/en/latest/news/2016/06/nigeria-killing-of-unarmed-pro-biafra-suppo rters-by-military-must-be-urgently-investigated/ on 3 April 2018.

Anisin, A. I. (2015). State repression, nonviolence, and protest mobilization $\mathrm{PhD}$ Thesis University of Essex

Bengtsson, M. (2016). How to plan and perform a qualitative study using content analysis NursingPlus Open, 2(1), 8-14

Boykoff, J. (2007). Limiting Dissent: The mechanisms of state repression in the USA Social Movement Studies, 6(3), 281-310.

Cunningham, D. (2003). State versus social movement: FBI counterintelligence against the New Left. In J. A. Goldstone (Ed.) States, parties, and social movements (pp. 45-77) Cambridge: Cambridge University Press.

Cunningham, D. (2004). There's something happening here: The new left, the Klan, and FBI counterintelligence (Berkeley: University of California Press).

della Porta, D. (1996). Social movements and the state: Thoughts on the policing of protest. In D. McAdam, J. McCarthy, \& M. N. Zald (Eds.), Comparative perspectives on social 
movements. political opportunities, mobilizing structures, and cultural framing (pp. 62-92). Cambridge/New York: Cambridge University Press.

della Porta, D., \& Diani, M. (2006). Social movements: An introduction (2nd ed.), Malden: Blackwell Publishing.

Diani, M. (1996). Linking mobilization frames and political opportunities: Insights from regional populism in Italy American Sociological Review, 61, 1053-69.

Earl, J. (2003). Tanks, tear gas, and taxes: Toward a theory of movement repression, Sociological Theory, 21(1), 46-68.

Earl, J. (2004). Controlling protest: New directions for research on the social control of protest, Research in Social Movements, Conflicts, and Change, 25, 55-83.

Fominaya, C. F., \& Wood, L. (2011). Repression and social movements Interface: A Journal for and about Social Movements, 3(1), 1-11.

Fukuyama, F. (2011). The origins of political order: From prehuman times to the French revolution. New York, NY: Farrar, Straus and Giroux.

Gamson, W., \& Meyer, D. S. (1996). Framing political opportunity In D. McAdam, J. D. McCarthy, \& M. N. Zald (Eds.), Opportunities, mobilizing structures, and framing (pp. 275-90). New York/Cambridge: Cambridge University Press.

García, O. J. M (2013) Soft repression and the current wave of social mobilisations in Spain. Social Movement Studies 13 (2):303-308. doi:10.1080/14742837.2013.863147

Gurr, T. R. (1970). Why men rebel, Princeton, NJ: Princeton University Press.

Hlaing, Y. K. (2007). The state of pro-democracy movement in authoritarian Burma Working Paper, No. 11, December, Washington: East-West Centre.

Human Rights Watch. (2005). 'Rest in pieces': Police torture and deaths in custody in Nigeria July 27. Retrieved from https://www.hrw.org/report/2005/07/27/rest-pieces/police-torture-and-deaths-custody-nigeria 27 February, 2018

Ibeanu, O., Orji, N., \& Iwuamadi, C. K. (2016). Biafra separatism: Causes, consequences, and remedies Enugu: Institute for Innovations in Development.

John A. B., \& Patricia, B. R. (2000). The effects of repression, political violence, and pain and loss on social capital in Central America Prepared for presentation at the XXII International Congress of the Latin American Studies Association, Miami, March 16-18, 2000. Retrieved from http://lasa.international.pitt.edu/Lasa2000/Booth-Richard.PDF on 3 April 2018

Kriesi, H. (2004). Political context and opportunity In Snow, Davis A. S., Sarah H. \& Kriesi, H. (Eds.), The Blackwell Companion to Social Movements (pp. 67-90). Oxford: Blackwell.

Madiebo, A. A. (1980). The Nigerian revolution and Biafran war. Enugu: Fourth Dimension Publishing Co. Ltd.

McAdam, D., McCarthy, J.,\& Zald, M. N. (eds.) (1996). Comparative perspective on social movements: political opportunities, mobilizing structures, and cultural framing. Cambridge/New York: Cambridge University Press.

Menoret, P. (2016). Repression and protest in Saudi Arabia Middle-East Brief Crown Centre 
for Middle East Studies, No. 101, August Brandeis University.

Mix, T. (2014). Lethal repression of peaceful protest in Africa: Why do (non)Accountable and military regimes shoot MA Thesis Barcelona Institute of International Relations

Muller, E. N., \& Jukam, T. O. (1983) Discontent and aggressive political participation. British Journal of Political Science, 13(2), 159-179.

Okeke, R. C. (2016). Relative deprivation, identity politics and the neo-Biafran movement in Nigeria: critical issues of nation-building in a postcolonial African state International Letters of Social and Humanistic Sciences, 66, 73-80.

Onuoha, G. (2012). Contemporary Igbo nationalism and the crisis of self-determination in Nigeria. African Studies, 71(1), 29-51.

Onuoha, G. (2014). The Politics of 'Hope' and 'Despair': Generational dimensions to Igbo nationalism in post-Civil War Nigeria African Sociological Review, 18(1), 2-26.

Owen, O. (2016). The New Biafrans: Historical imaginations and structural conflicts in Nigeria's separatist revival Paper presented at a seminar in the Changing Character of War series Pembroke College, University of Oxford, on 8 March 2016.

Siollun, M. (2009). Oil, politics and violence: Nigeria's military coup culture (1966-1976). New York: Algora Publishing.

Tarrow, S. (1994). Power in movement: Social movements, collective action and politics. New York/Cambridge: Cambridge University Press.

Ukiwo, U. (2009). Violence, identity mobilization, and the reimagining of Biafra, African Development, 34(1), 9-30.

Weber, M. (1946). Politics as a Vocation In From Max Weber: Essays in Sociology, translated by H. H. Gerth and C. Wright Mills. Oxford: Oxford University Press.

\section{Newspaper articles and reports}

Adindu, G. (2012, March 26) Ojukwu, Biafra of the Mind The Vanguard Retrieved from https://www.vanguardngr.com/2012/03/ojukwu-biafra-of-the-mind/ on 17 March 2018

Ahiuma- Young, V. (2016, August 3) Address agitation of IPOB, others, Labour urges govt The Vanguard Retrieved from https://www.vanguardngr.com/2016/08/address-agitation-ipob-others-labour-urges-govt/ on 3 April 2018

Akasike, C. (2017, August 19) Police disperse protesting IPOB members in Port Harcourt The Punch Retrieved from http://punchng.com/police-disperse-protesting-ipob-members-in-port-harcourt/ on 3 April 2018

Akwagyiram, A. (2017, October 3) Tension grips Nigerian city as separatist leader goes missing Reuters Retrieved from https://www.reuters.com/article/us-nigeria-security-biafra/tension-grips-nigerian-city-as-separ atist-leader-goes-missing-idUSKCN1C81IT on 3 April 2018

Alaribe, U. (2016, August 30) RE-IPOB names new leader, list eminent persons to negotiate with FG The Vanguard Retrieved from https://www.vanguardngr.com/2016/08/re-ipob-names-new-leader-list-eminent-persons-to-ne 
gotiate-with-fg/ on 3 April 2018

Army to probe extra-judicial killing of IPOB, MASSOB members (2017b, March 9) The Vanguard

https://www.vanguardngr.com/2017/03/army-probe-extra-judicial-killing-ipob-massob-memb ers/ on 3 April 2018

Bandele, B. (2014, May 21) Why can't Nigerians watch country's biggest movie? CNN Retrieved from https://edition.cnn.com/2014/05/21/opinion/why-cant-nigerians-half-yellow-sun/index.html on 21 April 2018

BIAFRA SIT-AT-HOME: People count losses as IPOB, MASSOB count gain (2017a, June 3) The Vanguard Retrieved from https://www.vanguardngr.com/2017/06/biafra-sit-home-people-count-losses-ipob-massob-cou nt-gain/ on 3 April 2018

BIAFRA: Court grants bail to 26 IPOB members The Vanguard (2016a, January 20) Retrieved from https:/www.vanguardngr.com/2016/01/biafra-court-grants-bail-to-26-ipob-members/ on 3 April 2018

Biafra: We acted in self-defence - Army (2016b, June 1) The Vanguard Retrieved from https:/www.vanguardngr.com/2016/06/biafra-acted-self-defence-army/ on 3 April 2018

Biafran agitator embarrass Imo State Governor (2016, October 3) Pulse Retrieved from http://www.pulse.ng/gist/pop-culture/rochas-okorocha-biafran-agitator-embarrass-imo-state-g overnor-id4784329.html on 3 April 2018

Chiedozie, I. (2017a, August 25) IPOB rejects withdrawal of quit notice, asks Igbo to leave North The Punch from http://punchng.com/breaking-ipob-rejects-withdrawal-of-quit-notice-asks-igbo-to-leave-north -\%E2\%80\%8E/ on 4 April 2018

Chiedozie, I. (2017b, October 11) IPOB accuses army, police of looting Kanu's house The Punch Retrieved from http://punchng.com/ipob-accuses-army-police-of-looting-kanus-house/ on 3 April 2018.

Court formally proscribes IPOB, designates it terrorist organisation (2017, September 21) This Day, Retrieved from https://www.thisdaylive.com/index.php/2017/09/21/court-formally-proscribes-ipob-designate s-it-terrorist-organisation/ on 3 April 2018

Daniel, S. (2017, September 17) IPOB mobilizing to humiliate Buhari in U.S, group raises the alarm The Vanguard Retrieved from https:/www.vanguardngr.com/2017/09/breaking-ipob-mobilizing-humiliate-buhari-u-s-northraises-alarm/ on 3 April 2018

Edike, T. (2014, March 13) We seized Enugu Govt House for 4 hours, says Onwuka, BZM leader The Vanguard Retrieved from https:/www.vanguardngr.com/2014/03/seized-enugu-govt-house-4-hours-says-onwuka-bzm-1 eader/ on 17 March 2018 
Efiong, P. U. (2017 December 23) Biafra and the politics of blame: The neo-Biafran consciousness and its challenges The Republic Retrieved from http://www.republic.com.ng/octobernovember-2017/biafra-politics-blame/ on 17 March 2018 Ekwe-Ekwe, H. (2006, July 13) Genocide against the Igbo continues in Onitsha.... USAfrica Online. Retrieved from <http://usafricaonline.com/ekwekwe.genocide2006.html $>$ [Accessed 7 March 2018]

Eze, J. (2017, September 16) Why we proscribed IPOB - South-east governors Premium Times Retrieved from https://www.premiumtimesng.com/news/headlines/243431-proscribed-ipob-south-east-gover nors.html on 3 April 2018

Ezea, S. (2017, May 16) Kanu's, Uwazuruike's travails and tempo of Biafra Struggle AllAfrica Retrieved from http://allafrica.com/stories/201705160817.html on March 302018

Gabriel, C., Agbakwuru, J., Yakubu, D., \& Agbo, D. (2017, September 18) Police arrest 59 IPOB members, say members will be tried as terrorists The Vanguard Retrieved from https:/www.vanguardngr.com/2017/09/police-arrest-59-ipob-members-say-members-will-trie d-terrorists/ on 30 March 2018

Half of a Yellow Sun film approved by Nigeria censors (2014, July 8) British Broadcasting Corporation (BBC) Retrieved from http://www.bbc.com/news/world-africa-28212955 on 21 March 2018

IPOB members clash with Hausa community in Rivers (2017c, September 12) The Vanguard Retrieved from https:/www.vanguardngr.com/2017/09/ipob-members-clash-hausa-community-rivers/ on 4 April 2018

Kazeem, Y., (2017, September 15) Operation Python Dance: Nigeria's use of brute force to stem Biafra agitation is stoking fears of conflict again Quartz Africa Retrieved from https://qz.com/1077801/biafra-and-nnamdi-kanu-nigerias-army-siege-to-crush-biafra-calls-is nt-winning-much-support/ on 3 April 2018

Le recensement se poursuit au Nigeria dans la violence (2006, March 23) Pana Press (PANA). Retrieved from $<$ http://www.panapress.com/freenewspor.asp? code $=$ fre121267\&dte=23/03/2006 $>$ [Accessed 3 July 2009]

MASSOB protests, seeks Jega's removal (2015, March 13) The Vanguard Retrieved from https:/www.vanguardngr.com/2015/03/massob-protests-seeks-jegas-removal/ on 3 April 2018

Muhammadu Buhari addresses nation on return from UK (2017, August 21) Al Jazeera Retrieved from https://www.aljazeera.com/news/2017/08/muhammadu-buhari-addresses-nation-return-uk-17 0821061530447.html on 3 April 2018

Nigeria to block IPOB funding sources (2017b, September 19) Daily Trust Retrieved from https://www.dailytrust.com.ng/nigeria-to-block-ipob-funding-sources.html on 3 April 2018 Nnamdi Kanu inaugurates Biafra Secret Service (2017, August 16) The Punch, Retrieved 
from http://punchng.com/video-nnamdi-kanu-inaugurates-biafra-secret-service/ on 3 April 2018

Nwaiwu, C., (2016, March 15) BIAFRA: Police secretly killed 20 of our members -MASSOB The Vanguard Retrieved from https:/www.vanguardngr.com/2016/03/biafra-police-secretly-killed-20-of-our-members-mass ob/ on 3 March 2018

Oduah, C., (2017, May 28) Biafran secessionist movement grows stronger in Nigeria Voice of America Retrieved from https:/www.voanews.com/a/biafran-secessionist-movement-grows-nigeria/3873873.html

Okakwu, E., (2017, April 16) Is Nigerian govt violating court orders by detaining Biafra leader Nnamdi Kanu? Premium Times Retrieved from https://www.premiumtimesng.com/news/headlines/228891-fact-check-nigerian-govt-violatin g-court-orders-detaining-biafra-leader-nnamdi-kanu.html on 3 April 2018

Okoli, A., (2017, September 16) Abia further extends the curfew in Aba The Vanguard Retrieved from https://www.vanguardngr.com/2017/09/abia-extends-curfew-aba/ on 3 April 2018

Okute, P., (2015, October 12) Radio Biafra: Making sense of nonsense The Source

Okutu, P., \& Agbo, D., (2017, September 8) Our position on killing of IPOB members S-East govs The Vanguard Retrieved from https:/www.vanguardngr.com/2017/09/position-killing-ipob-members-s-east-govs/ on 3 April 2018

Onuchukwu, B., (2012, June 6) Security personnel raid Onitsha MASSOB offices, kill 16 AllAfrica Retrieved from http://allafrica.com/stories/201206061004.html on 3 April 2018

Opejob, S. (2017, September 27) Biafra: Ekweremadu, Abaribe, other Igbo Senators meet Buhari over IPOB, Nnamdi Kanu Daily Post Retrieved from http://dailypost.ng/2017/09/27/biafra-ekweremadu-abaribe-igbo-senators-meet-buhari-ipob-n namdi-kanu/ on 3 April 2018

Our lives under Python Dance II - South-East residents speak (2017a, September 24) Daily Trust, Retrieved from https://www.dailytrust.com.ng/our-lives-under-python-dance-ii-south-east-residents-speak.ht $\mathrm{ml}$ on 3 April 2018

Police arrest MASSOB members for forcing catholic priest to conduct mass (2015, September 17) Daily Sun

Police summon Uwazurike over MASSOB crisis (2014, August 22) Daily Trust Retrieved from

https://www.dailytrust.com.ng/news/general/police-summon-uwazurike-over-massob-crisis/5 4501.html on 3 April 2018

Salaudeen, O., (2016, August 7) Biafra impossible through court -Prof. Ben Nwabueze The Sun Retrieved from http://sunnewsonline.com/biafra-impossible-through-court-prof-ben-nwabueze/ on 3 April 2017 


\section{Macrothink}

Journal of Social Science Studies

ISSN 2329-9150

2018, Vol. 5, No. 2

South-East governors ban IPOB activities (2017, September 15) Channels Television Retrieved from https://www.channelstv.com/2017/09/15/breaking-south-east-governors-ban-ipob-activities/ on 3 April 2018

\section{Online}

Google Trends (2018) Retrieved from https://en.wikipedia.org/wiki/Google_Trends on 21 April 2018.

\section{Copyright Disclaimer}

Copyright for this article is retained by the author(s), with first publication rights granted to the journal.

This is an open-access article distributed under the terms and conditions of the Creative Commons Attribution license (http://creativecommons.org/licenses/by/3.0/). 